\title{
Reform and Change in Inclusive Education: A Tribute to Judy Lupart
}

\author{
Joanne Deppeler \\ Monash University
}

Founding Editor of the journal Exceptionality Education Canada, Judy Lupart's research, publication, and teaching interests have included an important focus on inclusive education and school transformation. Two of her papers relevant to this work were published in Exceptionality Education Canada a decade apart:

Lupart, J. (1992). Toward a unified system of education: Where do we go from here? Exceptionality Education Canada, 2(1/2), 1-7.

Lupart, J., \& Webber, C. (2002). Canadian schools in transition: Moving from dual education systems to inclusive schools. Exceptionality Education Canada, 12(2/3), 7-52.

Ten years later, and on the occasion of her retirement as Co-editor at Exceptionality Education International, I would like to pay tribute to Judy Lupart and make comment on these two papers in light of inclusive education today.

Together the papers describe the advances in the progress of the inclusion of students with 'exceptional learning needs' and the gaps in educational provision, as well as identify the need for a unified system of education in Canada. The papers distilled and synthesized inclusive educational reform in Canadian schools. In doing so, they drew to our attention the complex and multi-faceted nature of these reform efforts and the need for innovative problem solving to achieve the goal of 'excellent education for all students.' Lupart and Webber (2002) drew our attention to the separate and parallel planes in which educational reform in regular and special education were taking place. Their analyses challenged the dominance of 'top-down' approaches and suggested that narrowly focused agendas (e.g., raising performance standards) could further reduce the prospects for greater equity.

Ten years on, many of the key issues and challenges identified remain and are highly relevant to inclusive education reform efforts worldwide. Conditions that were highlighted as necessary for developing inclusive schools included the need for collaborative versus competitive organizational structures and schools where teachers were central to shaping change processes. These conditions are consistent with current thinking and have been linked to increased student achievement and positive changes in teachers' practices. This history of special provision for children with exceptional needs in Canadian schools allows us to reflect on the substantive progress and development that has been achieved. At the same time, these papers 
remind us to be vigilant as in many respects very little has changed over the past three decades. The insights gained from the critique offer some real grounds for generating alternative school change approaches. Well in advance of current 'standards-based reform' that attempts to ensure students achieve common educational standards, these papers provided contemporary thinking for conceiving and exploring school change. They offer us a frame from which to examine where we have come from and to critically consider what the agendas might be for moving inclusive schooling forward. We are reminded that inclusive schooling should be based on values of equity and democracy and promote a high quality education 'for all.' The papers challenge us to place educational and social aims at the centre of a discussion of educational change and call for serious rethinking and reworking of inclusive education reform.

My thanks go to Judy Lupart, a colleague and friend, whose intellect and energy has long inspired many of us to continue in our efforts to meet these challenges. She is an exemplary academic in the field of inclusive education both in Canada and internationally.

\section{Author's Note}

Correspondence concerning this commentary should be addressed to Joanne Deppeler, Monash University, PO Box 6 Clayton 3800, Victoria, AUSTRALIA.

Email: joanne.deppeler@monash.edu.au 